\title{
Effects of air temperature and blanching pre-treatment on phytochemical content, antioxidant activity and enzyme inhibition activities of Thai basil leaves (Ocimum basilicum var. thyrsiflorum)
}

\author{
${ }^{1,2^{*}}$ Le, N.L., ${ }^{1,2}$ Le, T.T.H. and ${ }^{1,2,3}$ Ma, N.B. \\ ${ }^{1}$ School of Biotechnology, International University, Quarter 6, Linh Trung Ward, Thu Duc District, Ho Chi \\ Minh City, Viet Nam \\ ${ }^{2}$ Vietnam National University, Ho Chi Minh City, Vietnam \\ ${ }^{3}$ Institute of Applied Science and Technology, Van Lang University, 80/68 Duong Quang Ham Street, 13 \\ Ward, Binh Thanh District, Ho Chi Minh City, Vietnam
}

\begin{abstract}
Article history:
Received: 29 July 2020

Received in revised form: 6

September 2020

Accepted: 15 October 2020

Available Online: 24 January

2021
\end{abstract}

Keywords:

Thai basil,

Blanching,

Antioxidant,

$\mathrm{DPPH}$,

Drying,

Starch-digesting enzymes

DOI:

https://doi.org/10.26656/fr.2017.5(1).403

\begin{abstract}
Thai basil leaves (Ocimum basilicum var. thyrsiflorum) have been used in food flavoring and traditional medicine. Hot-air drying is a convenient and low-cost method to preserve them for long-term use but causes the loss of their bioactive compounds during the process. In this work, the effect of pre-blanching on preserving these characteristics of Thai basil leaves dried at different air temperatures was studied. The antioxidant characteristics were evaluated by the contents of total phenolics, total flavonoids and total chlorophylls and the scavenging capacity against 2,2-diphenyl-1-picrylhydrazyl (DPPH) radicals. In addition, the inhibitory activities against starch-digesting enzymes were assessed with $\alpha$-amylase and amyloglucosidase. At the air temperature of $50^{\circ} \mathrm{C}$, antioxidant characteristics of dried leaves with pre-blanching were proven better than those without blanching and came close to those of the fresh sample. The drying temperature had more evident effects on inhibitory activities against starch-digesting enzymes than blanching. These activities of hot-air dried leaves were comparable to those of the fresh one. This study could provide insights into the integration of blanching and hot-air drying to preserve medicinal plants.
\end{abstract}

\section{Introduction}

Basil (Ocimum basilicum L.) is a popular herb used in various dishes in the US and Mediterranean area. It is originated from the warm tropical countries such as Africa and southern Asia but now broadly cultivated around the world (Hiltunen and Holm, 2003). It has been reported to possess antioxidant activities implying its potential human health benefits (Yanishlieva et al., 2006). Its antioxidant activities are attributed to its phenolic and aromatic compounds. The importance, historic usage, phenolics and essential oils of basil have been comprehensively summarized by Makri and Kintzios (2008). It has diverse varieties with between 65 and 150 species reported. Thai basil (Ocimum basilicum var. thyrsiflorum) is a type of basil native to Southeast Asia.

In order to preserve this seasonal and easily spoiled herb available to consumers during the whole year, many technologies can be applied, such as drying (Beatovic et al., 2015). Drying is among the most ancient preservation technologies, which can terminate certain biochemical changes in perishable plants by reducing their moisture content. As a result, it lengthens the storage period, minimize packaging requirements and lessen transport weights (Okos, 1992). In the ancient era, natural sun drying was used for food preservation, including agricultural products. However, this technique has several drawbacks such as highly possible contamination with foreign objects; severe weather dependence and long drying duration possibly leading to the deterioration of active compounds. Therefore, close systems/equipment are required to conduct drying for better control and quality preservation of the final products (Ertekin and Yaldiz, 2004). With that consideration, hot air dryers, which promote faster and more uniform drying process with higher hygiene, have become common for industrial practices.

In this study, hot-air drying was applied to preserve 
Thai basil leaves and blanching was employed and different air temperatures were studied to investigate their impacts on the contents of phytochemicals such as phenolics, flavonoids and chlorophylls, their antioxidant activity and inhibitory effects against digesting enzymes such as alpha-amylase and amyloglucosidase in the dried leaves. The integration of pre-blanching and hot-air drying could be as an efficient and low-cost alternative approach for plant preservation.

\section{Materials and methods}

\subsection{Materials and chemicals}

Thai basil was purchased from a local farm in Ho Chi Minh City, Vietnam. The chemicals used for the analyses include methanol, ethanol, Folin-Ciocalteu reagent, sodium carbonate, aluminum chloride, potassium acetate, sodium chloride, dinitrosalicylic acid, rutin, gallic acid and 2,2-diphenyl-1-picrylhydrazyl (DPPH), p-nitrophenyl $\alpha$-D-glucoside, of analytical grade purchased from Merk or Sigma-Aldrich. The enzymes alpha-amylase from Aspergillus oryzae ( 30 U/ $\mathrm{mg})$ and amyloglucosidase from Asperigillus niger $(\sim 300$ $\mathrm{U} / \mathrm{mL}$ ) was purchased from Sigma-Aldrich.

\subsection{Drying experiments}

The whole basil was washed with tap water and drained off. If blanching pre-treatment was employed, the basil would be blanched in boiling water (approximate $100^{\circ} \mathrm{C}$ ) for $10 \mathrm{~s}$. The excess water was removed by tissues. The leaves were then separated from stems. Drying experiments were performed in a laboratory-scale cabinet air-ventilated and forcedconvection dryer (SOF-W155, Korea) with a constant air velocity of $1.2 \mathrm{~m} / \mathrm{s}$. The air temperature was kept at 50 , 60,70 , and $80^{\circ} \mathrm{C}$. The dryer was operated for $30 \mathrm{mins}$ to obtain the set air temperature before loading the samples. Basil leaves of $100 \pm 0.5 \mathrm{~g}$ for each experiment were uniformly distributed on trays and put in the dryer. The drying process was conducted until the moisture content reached approximately $7 \%$ (wet basis), which was low enough for their long practical storage (Phahom et al.,
2017). The drying durations for the leaves without blanching at $50,60,70$ and $80^{\circ} \mathrm{C}$ were $270,175,115$ and 70 mins, respectively. These values were 175, 110, 65 and $60 \mathrm{~min}$ respectively for the processes with preblanching. The dried leaves were ground by an IKA A11 grinder and stored in clean bags in a desiccator until extraction for chemical analyses.

\subsection{Chemical analyses}

The antioxidant properties of dried leaves were characterized by the contents of total phenolics (TPC) (Thaipong et al., 2006), total flavonoids (TFC) (Chang et al., 2002) and chlorophylls (TCC) (Kumar et al., 2015); and the antioxidant capacity of scavenging 2,2-diphenyl1-picrylhydrazyl (DPPH) free radicals (Thaipong et al., 2006). The inhibitory capacities of dried leaves against starch digestibility were in vitro analyzed through their effects on carbohydrate digesting enzymes including $\alpha$ amylase and amyloglucosidase (Bhandari et al., 2008). For TPC, TFC, DPPH and enzyme inhibition tests, the basil weight of $1 \mathrm{~g}$ was extracted 3 times with $20 \mathrm{~mL}$ methanol at room temperature. For TCC determination, the basil weight of $1 \mathrm{~g}$ was extracted 3 times with $10 \mathrm{~mL}$ $80 \%(\mathrm{v} / \mathrm{v})$ acetone at room temperature.

\subsection{Statistical analysis}

All data were the means of triplicate measurements. The statistical analyses were conducted using one-way ANOVA with the SPSS software version 22.0 at a level of confidence of $95 \%$.

\section{Results and discussion}

\subsection{Antioxidant characteristics of dried leaves}

Antioxidant characteristics of dried leaves were evaluated through the contents of various potential antioxidants such as phenolics, flavonoids and chlorophylls; and through their capacity in scavenging DPPH free radicals. Table 1 illustrates that total phenolic content (TPC) ranged from 4.83 to $15.44 \mathrm{mg}$ gallic acid equivalent (GAE)/g dry matter (DM) for hot-air dried leaves without blanching pre-treatment. In addition, it

Table 1. Effects of blanching pre-treatment and hot air temperature on total phenolic content (TPC), total flavonoid content (TFC), total chlorophyll content (TCC) and DPPH scavenging capacity of air-dried Thai basil leaves

\begin{tabular}{|c|c|c|c|c|c|c|c|c|}
\hline \multirow{2}{*}{ Sample } & \multicolumn{2}{|c|}{$\begin{array}{c}\text { TPC } \\
\text { (mg GAE/g DM) } \\
\end{array}$} & \multicolumn{2}{|c|}{$\begin{array}{c}\text { TFC } \\
\text { (mg RE/g DM) } \\
\end{array}$} & \multicolumn{2}{|c|}{$\begin{array}{c}\text { TCC } \\
(\mu \mathrm{g} / \mathrm{g} D M) \\
\end{array}$} & \multicolumn{2}{|c|}{$\begin{array}{c}\text { DPPH scavenging capacity } \\
(\%)\end{array}$} \\
\hline & No Blanc & $\begin{array}{c}\text { With } \\
\text { Blanching }\end{array}$ & No Blanching & $\begin{array}{c}\text { With } \\
\text { Blanching }\end{array}$ & No Blanching & $\begin{array}{c}\text { With } \\
\text { Blanching }\end{array}$ & No Blanching & $\begin{array}{c}\text { With } \\
\text { Blanching }\end{array}$ \\
\hline Fresh & $80.67 \pm$ & $129.17 \pm 1.96^{\mathrm{a}}$ & $14.94 \pm$ & $20.71 \pm 1.70^{\mathrm{a}}$ & $191.1 \pm 20.3^{\mathrm{a}}$ & $187.4 \pm 1.2^{\mathrm{a}}$ & 89.5 & $92.85 \pm 0.93^{\mathrm{a}}$ \\
\hline $50^{\circ} \mathrm{C}$ & $14.17 \pm 1.41^{\mathrm{e}}$ & $108.33 \pm 13.54^{b}$ & $8.53 \pm 0.20^{\mathrm{de}}$ & $18.11 \pm 1.70^{\mathrm{b}}$ & $214.9 \pm 28.4^{\mathrm{a}}$ & $139.5 \pm 7.5^{\mathrm{b}}$ & $40.15 \pm 0.92^{b}$ & $93.11 \pm 0.57^{\mathrm{a}}$ \\
\hline $60^{\circ} \mathrm{C}$ & $4.83 \pm 0.51^{\mathrm{f}}$ & $95.56 \pm 7.74^{\mathrm{c}}$ & $7.38 \pm 0.45^{\mathrm{e}}$ & $14.43 \pm 0.82^{\mathrm{c}}$ & $217.7 \pm 11.6^{\mathrm{a}}$ & $136.0 \pm 11.9^{b}$ & $23.36 \pm 0.02^{\mathrm{c}}$ & $89.38 \pm 0.11^{\mathrm{a}}$ \\
\hline $70^{\circ} \mathrm{C}$ & $7.44 \pm 3.36^{\mathrm{ef}}$ & $90.78 \pm 2.58^{c}$ & $9.09 \pm 0.71^{\mathrm{d}}$ & $13.62 \pm 0.15^{\mathrm{c}}$ & $198.9 \pm 13.6^{\mathrm{a}}$ & $126.9 \pm 23.9^{b c}$ & $22.15 \pm 1.23^{\mathrm{c}}$ & $89.53 \pm 0.56^{\mathrm{a}}$ \\
\hline $80^{\circ} \mathrm{C}$ & $15.44 \pm 3.85^{\mathrm{e}}$ & $107.83 \pm 3.50^{\mathrm{b}}$ & $8.24 \pm 0.20^{\mathrm{de}}$ & $14.86 \pm 1.03^{\mathrm{c}}$ & $120.5 \pm 0.6^{\mathrm{bc}}$ & $89.7 \pm 23.4^{\mathrm{c}}$ & $23.93 \pm 2.04^{\mathrm{c}}$ & $89.29 \pm 0.23^{\mathrm{a}}$ \\
\hline
\end{tabular}

Values are expressed as mean \pm standard deviation. Values with different superscript within the column are significantly different $(\mathrm{p}<0.05)$. 
also shows that $50^{\circ} \mathrm{C}$ and $80^{\circ} \mathrm{C}$ could preserve phenolic compounds better than $60^{\circ} \mathrm{C}$ and $70^{\circ} \mathrm{C}$. There was no statistically significant difference $(\mathrm{p}>0.05)$ in total phenolic contents (TPCs) at $50^{\circ} \mathrm{C}$ and $80^{\circ} \mathrm{C}$. The degradation of antioxidants depends not only on the air temperature but also on processing time. Higher temperature and/or longer duration promote more degradation. At $80^{\circ} \mathrm{C}$, shorter drying time induced by high temperature leads to higher retention of bioactive compounds than at $70^{\circ} \mathrm{C}$. Besides, the elevated temperature may also denature catalytic enzymes that oxidize phenolic compounds. Similar results have also been reported in previous studies (Deng et al., 2016). An identical trend was also observed for the blanched Thai basil leaves. However, blanching could retain total phenolic content better during drying, which was in the range of 90.78 to $108.33 \mathrm{mg}$ GAE/g DM. This is because blanching could prevent enzymatically induced deterioration of phenolic compounds in vegetables and fruits such as the enzyme polyphenoloxidase or peroxidase (Heras-Ramírez et al., 2012). Table 1 also expresses that the fresh samples unsurprisingly had significantly higher TPC values $(\mathrm{p}<0.05)$. However, the differences in TPC between hot-air dried and fresh samples significantly reduces with the aid of blanching.

The total flavonoid content (TFC) of dried Thai basil leaves was also significantly affected by hot air temperature and blanching pre-treatment $(\mathrm{p}<0.05)$ (Table 1). Their TFC values were in the ranges of $7.38-9.09 \mathrm{mg}$ rutin equivalent $(\mathrm{RE}) / \mathrm{g} \mathrm{DM}$ and 13.62-18.11 mg RE/g DM for hot-air dried leaves without and with blanching, respectively. Among them, the blanched sample dried at $50^{\circ} \mathrm{C}$ showed the highest TFC, indicating this condition is the best in retaining flavonoids. Identical effects have also been reported for other materials (Heras-Ramírez et al., 2012). Similarly to the trend observed for TPC, fresh samples contained significantly higher TFCs $(p<0.05)$ than dried samples, but blanching could narrow the difference.

In addition to its action as an antioxidant, chlorophyll is also a natural pigment to make green color for Thai basil leaves. Table 1 exhibited that except for the sample dried at $80^{\circ} \mathrm{C}$, the samples dried at lower temperatures showed no statistically significant differences on chlorophyll content $(p>0.05)$. These contents were also insignificantly different $(p>0.05)$ with that of the fresh sample in case of no blanching treatment. High temperature is believed to have negative effects on chlorophyll retention. It denatures lipoproteins that are bound with chlorophyll, lowers their protective effects and hence leads to chlorophyll losses (Inyang and Ike, 1998). During heat treatment, the magnesium in chlorophyll molecules is also readily leaked out to transform chlorophyll into pheophytin (Arslan and Özcan, 2010). These undesirable impacts were observed at $80^{\circ} \mathrm{C}$. Similar results were reported for other leafy vegetables dried at $100^{\circ} \mathrm{C}$ (Negi and Roy, 2000). In addition, Table 1 indicates that blanching unexpectedly and significantly reduced the chlorophyll content of samples. In fact, blanching has two contrary effects on chlorophyll retention of agricultural produces. On the one hand, it deactivates the chlorophyll-degrading enzyme chlorophyllase and reduces oxygen in plant tissues facilitating the preservation of chlorophyll in the later stages (Brewer et al., 1995). On the other hand, it also creates irreversible changes in cell structure, increases the permeability of cytoplasmic membranes or disrupts chloroplast and chromoplasts (Cui et al., 2004). These changes lead to the diffusion of chlorophyll into blanching medium causing its physical loss or making chlorophyll readily exposed to unfavorable conditions causing its degradation. The latter reason explains the reduction of chlorophyll content caused by blanching in this study.

The antioxidant capacity of Thai basil leaves dried at different air temperatures and pre-treatments are evaluated through the scavenging capacity of DPPH free radicals as shown in Table 1 . The DPPH method is preferable because it is quick, easy and reliable. Table 1 indicates that drying temperature had an evident effect on the antioxidant capacity of unblanched Thai basil leaves but such differences among blanched samples were insignificant $(p>0.05)$, which was comparable $(p>0.05)$ with the value of the fresh sample. Blanching significantly improved the antioxidant capacity of dried leaves, for example increasing from $40.2 \%$ to $93.1 \%$ at $50^{\circ} \mathrm{C}$. A high correlation $\left(\mathrm{R}^{2}=0.932\right)$ was confirmed for the relationship of DPPH radical scavenging capacity and total phenolic content while no obvious correlations were found for total flavonoid and chlorophyll contents. This implies that the contribution of phenolic compounds to antioxidant properties of Thai basil leaves may be dominant.

\subsection{Inhibitory capacities against starch-hydrolyzing enzymes of dried leaves}

Inhibition of enteric enzymes including $\alpha$-amylase and amyloglucosidase is considered as a therapeutic approach to limit carbohydrate absorption after food intake, which helps to control blood glucose levels and reduce the risk of diabetes development (Inzucchi, 2002). Table 2 expresses that dried Thai basil leaves had inhibitory capacities against both $\alpha$-amylase and amyloglucosidase, where the effect on $\alpha$-amylase was stronger. The drying temperature had significant effects $(p<0.05)$ on inhibitory capacities against both enzymes 
Table 2. Effects of blanching pre-treatment and hot air temperature on inhibitory capacities of air-dried Thai basil leaves against alpha-amylase and amyloglucosidase

\begin{tabular}{lcccc}
\hline \multirow{2}{*}{ Sample } & \multicolumn{2}{c}{ Alpha-amylase inhibition (\%) } & \multicolumn{2}{c}{ Amyloglucosidase inhibition (\%) } \\
\cline { 2 - 5 } & No Blanching & With Blanching & No Blanching & With Blanching \\
\hline Fresh & $65.58 \pm 0.75^{\mathrm{ab}}$ & $65.48 \pm 2.39^{\mathrm{ab}}$ & $5.10 \pm 1.02^{\mathrm{f}}$ & $13.95 \pm 2.57^{\mathrm{de}}$ \\
$50^{\circ} \mathrm{C}$ & $65.53 \pm 0.74^{\mathrm{ab}}$ & $64.74 \pm 4.71^{\mathrm{ab}}$ & $14.63 \pm 3.58^{\mathrm{de}}$ & $12.93 \pm 3.12^{\mathrm{e}}$ \\
$60^{\circ} \mathrm{C}$ & $68.10 \pm 2.22^{\mathrm{a}}$ & $63.66 \pm 3.00^{\mathrm{b}}$ & $17.01 \pm 2.95^{\mathrm{cde}}$ & $18.71 \pm 4.25^{\mathrm{dcd}}$ \\
$70^{\circ} \mathrm{C}$ & $58.48 \pm 1.33^{\mathrm{c}}$ & $58.23 \pm 0.17^{\mathrm{c}}$ & $23.13 \pm 5.80^{\mathrm{ab}}$ & $26.19 \pm 1.18^{\mathrm{a}}$ \\
$80^{\circ} \mathrm{C}$ & $57.20 \pm 0.76^{\mathrm{c}}$ & $34.47 \pm 1.26^{\mathrm{d}}$ & $20.41 \pm 2.04^{\mathrm{bc}}$ & $21.77 \pm 1.18^{\mathrm{abc}}$ \\
\hline
\end{tabular}

Values are expressed as mean \pm standard deviation. Values with different superscript within the column are significantly different $(\mathrm{p}<0.05)$.

while blanching did not show obvious effects, except at $80^{\circ} \mathrm{C}$ for $\alpha$-amylase and the fresh sample for amyloglucosidase. The dried leaves at $50^{\circ} \mathrm{C}$ and $60^{\circ} \mathrm{C}$ exhibited the highest inhibitory capacity against $\alpha$ amylase which was statistically equivalent $(p>0.05)$ to that of the fresh sample. Interestingly, the drying temperature of $70^{\circ} \mathrm{C}$ indicated the strongest inhibitory capacity against amyloglucosidase which was significantly higher than that of the fresh sample. No evident correlations between TPC or TFC and $\alpha$-amylase and amyloglucosidase inhibitory activities were found. Several previous reports have suggested a correlation between polyphenolic content of plants and their inhibitory effect (Mai et al., 2007; Apostolidis and Lee, 2010; Ramkumar et al., 2010). However, besides phenolics, many other phytochemicals have also been identified to possess the inhibitory activity such as flavonoids (Cui et al., 2019), alkaloids (Ramkumar et al., 2007), limonoids (Ponnusamy et al., 2015), peptides (Yu et al., 2011), terpenoids (Loizzo et al., 2007; Bhat et al., 2011), and miscellaneous substances (Kumar et al., 2011). As a result, it is not feasible to predict the inhibitory activities of the extract against $\alpha$-amylase and amyloglucosidase based on a specific substance.

\section{Conclusion}

In this study, the effects of blanching pre-treatment and air temperature on antioxidant properties and enzyme inhibition of dried Thai basil leaves were investigated in-depth. The results showed that the combination of pre-blanching and hot air drying at $50^{\circ} \mathrm{C}$ could minimize the loss of bioactive compounds and their activities, providing close values with those of fresh samples. There was an evident correlation between total phenolic content and the DPPH scavenging capacity while no clear correlation was found among the contents of studied bioactive compounds with inhibitory capacities against alpha-amylase and amyloglucosidase.

\section{Conflict of interest}

The authors declare no conflict of interest.

\section{Acknowledgments}

The study was supported by The Youth Incubator for Science and Technology Program, managed by Youth Development Science and Technology Center - Ho Chi Minh Communist Youth Union and Department of Science and Technology of Ho Chi Minh City, the contract number is "19/2019/HĐ-KHCNT-VU".

\section{References}

Apostolidis, E. and Lee, C. (2010). In vitro potential of Ascophyllum nodosum phenolic antioxidantmediated $\alpha$-glucosidase and $\alpha$-amylase inhibition. Journal of Food Science, 75(3), H97-H102. https:// doi.org/10.1111/j.1750-3841.2010.01544.x

Arslan, D. and Özcan, M.M. (2010). Study the effect of sun, oven and microwave drying on quality of onion slices. LWT-Food Science and Technology, 43(7), 1121-1127. https://doi.org/10.1016/j.lwt.2010.02.019

Beatovic, D., Krstic-Milosevic, D., Trifunovic, S., Siljegovic, J., Glamoclija, J., Ristic, M. and Jelacic, S. (2015). Chemical composition, antioxidant and antimicrobial activities of the essential oils of twelve Ocimum basilicum L. cultivars grown in Serbia. Records of Natural Products, 9(1), 62-75.

Bhandari, M.R., Jong-Anurakkun, N., Hong, G. and Kawabata, J. (2008). $\alpha$-Glucosidase and $\alpha$-amylase inhibitory activities of Nepalese medicinal herb Pakhanbhed (Bergenia ciliata, Haw.). Food Chemistry, 106(1), 247-252. https://doi.org/10.1016/ j.foodchem.2007.05.077

Bhat, M., Zinjarde, S.S., Bhargava, S.Y., Kumar, A.R. and Joshi, B.N. (2011). Antidiabetic Indian plants: a good source of potent amylase inhibitors. EvidenceBased Complementary and Alternative Medicine, 2011,810207. https://doi.org/10.1093/ecam/nen040

Brewer, M.S., Begum, S. and Bozeman, A. (1995). Microwave and conventional blanching effects on chemical, sensory, and color characteristics of frozen broccoli. Journal of Food Quality, 18(6), 479-493. https://doi.org/10.1111/j.1745-4557.1995.tb00398.x 
Chang, C.C., Yang, M.H., Wen, H.M. and Chern, J.C. (2002). Estimation of total flavonoid content in propolis by two complementary colorimetric methods. Journal of Food and Drug Analysis, 10(3), 178-182. https://doi.org/10.38212/2224-6614.2748

Cui, H., Lu, T., Wang, M., Zou, X., Zhang, Y., Yang, X., Dong, Y. and Zhou, H. (2019). Flavonoids from Morus alba L. leaves: Optimization of extraction by response surface methodology and comprehensive evaluation of their antioxidant, antimicrobial, and inhibition of $\alpha$-amylase activities through analytical hierarchy process. Molecules, 24(13), 2398-2414. https://doi.org/10.3390/molecules24132398

Cui, Z.W., Xu, S.Y. and Sun, D.W. (2004). Effect of microwave-vacuum drying on the carotenoids retention of carrot slices and chlorophyll retention of Chinese chive leaves. Drying Technology, 22(3), 563 -575. https://doi.org/10.1081/DRT-120030001

Deng, L.Z., Yang, X.H., Mujumdar, A., Zhao, J.H., Wang, D., Zhang, Q., Wang, J., Gao, Z.J. and Xiao, H.W. (2018). Red pepper (Capsicum annuиm L.) drying: effects of different drying methods on drying kinetics, physicochemical properties, antioxidant capacity, and microstructure. Drying Technology, 36 (8), 893-907. https:// doi.org/10.1080/07373937.2017.1361439

Ertekin, C. and Yaldiz, O. (2004). Drying of eggplant and selection of a suitable thin layer drying model. Journal of Food Engineering, 63(3), 349-359. https://doi.org/10.1016/j.jfoodeng.2003.08.007

Heras-Ramírez, M.E., Quintero-Ramos, A., CamachoDávila, A.A., Barnard, J., Talamás-Abbud, R., Torres-Muñoz, J.V. and Salas-Muñoz, E. (2012). Effect of blanching and drying temperature on polyphenolic compound stability and antioxidant capacity of apple pomace. Food and Bioprocess Technology, 5(6), 2201-2210. https:// doi.org/10.1007/s11947-011-0583-x

Hiltunen, R. and Holm, Y. (2003). Basil: the genus Ocimum. USA: CRC Press.

Inyang, U. and Ike, C. (1998). Effect of blanching, dehydration method and temperature on the ascorbic acid, colour, sliminess and other constituents of okra fruit. International Journal of Food Sciences and Nutrition, 49(2), 125-130. https:// doi.org/10.3109/09637489809089392

Inzucchi, S.E. (2002). Oral antihyperglycemic therapy for type 2 diabetes: scientific review. The Journal of the American Medical Association, 287(3), 360-372. https://doi.org/10.1001/jama.287.3.360

Kumar, S., Narwal, S., Kumar, V. and Prakash, O. (2011). $\alpha$-Glucosidase inhibitors from plants: A natural approach to treat diabetes. Pharmacognosy Reviews, 5(9), 19-29. https://doi.org/10.4103/09737847.79096

Kumar, S.S., Manoj, P., Shetty, N.P. and Giridhar, P. (2015). Effect of different drying methods on chlorophyll, ascorbic acid and antioxidant compounds retention of leaves of Hibiscus sabdariffa L. Journal of the Science of Food and Agriculture, 95(9), 1812-1820. https:// doi.org/10.1002/jsfa.6879

Loizzo, M., Saab, A., Statti, G. and Menichini, F. (2007). Composition and $\alpha$-amylase inhibitory effect of essential oils from Cedrus libani. Fitoterapia, 78(4), 323-326. https://doi.org/10.1016/j.fitote.2007.03.006

Mai, T.T., Thu, N.N., Tien, P.G. and Van Chuyen, N. (2007). Alpha-glucosidase inhibitory and antioxidant activities of Vietnamese edible plants and their relationships with polyphenol contents. Journal of Nutritional Science and Vitaminology, 53(3), 267276. https://doi.org/10.3177/jnsv.53.267

Makri, O. and Kintzios, S. (2008). Ocimum sp.(basil): Botany, cultivation, pharmaceutical properties, and biotechnology. Journal of Herbs, Spices and Medicinal Plants, 13(3), 123-150. https:// doi.org/10.1300/J044v13n03_10

Negi, P. and Roy, S. (2000). Effect of blanching and drying methods on $\beta$-carotene, ascorbic acid and chlorophyll retention of leafy vegetables. LWT-Food Science and Technology, 33(4), 295-298. https:// doi.org/10.1006/fstl.2000.0659

Okos, M. (1992). Food dehydration. In Heldman D.R. and Lund, D.B. (Eds). Hand book of food engineering. $2^{\text {nd }}$ ed. USA: CRC Press.

Phahom, T., Kerr, W.L., Pegg, R.B. and Phoungchandang, S. (2017). Effect of packaging types and storage conditions on quality aspects of dried Thunbergia laurifolia leaves and degradation kinetics of bioactive compounds. Journal of Food Science and Technology, 54(13), 4405-4415. https:// doi.org/10.1007/s13197-017-2917-9

Ponnusamy, S., Haldar, S., Mulani, F., Zinjarde, S., Thulasiram, H. and RaviKumar, A. (2015). Gedunin and azadiradione: human pancreatic alpha-amylase inhibiting limonoids from neem (Azadirachta indica) as anti-diabetic agents. PloS One, 10(10), 1-19. https://doi.org/10.1371/journal.pone.0140113

Ramkumar, K., Rajaguru, P. and Ananthan, R. (2007). Antimicrobial properties and phytochemical constituents of an antidiabetic plant Gymnema montanum. Advances in Biological Research, 1(1-2), 67-71. 
Ramkumar, K.M., Thayumanavan, B., Palvannan, T. and Rajaguru, P. (2010). Inhibitory effect of Gymnema Montanum leaves on $\alpha$-glucosidase activity and $\alpha$ amylase activity and their relationship with polyphenolic content. Medicinal Chemistry Research, 19(8), 948-961. https://doi.org/10.1007/ s00044-009-9241-5

Thaipong, K., Boonprakob, U., Crosby, K., CisnerosZevallos, L. and Byrne, D.H. (2006). Comparison of ABTS, DPPH, FRAP, and ORAC assays for estimating antioxidant activity from guava fruit extracts. Journal of Food Composition and Analysis, 19(6-7), 669-675. https://doi.org/10.1016/ j.jfca.2006.01.003

Yanishlieva, N.V., Marinova, E. and Pokorný, J. (2006). Natural antioxidants from herbs and spices. European Journal of Lipid Science and Technology, 108(9), 776-793. https://doi.org/10.1002/ ejlt.200600127

Yu, Z., Yin, Y., Zhao, W., Yu, Y., Liu, B., Liu, J. and Chen, F. (2011). Novel peptides derived from egg white protein inhibiting alpha-glucosidase. Food Chemistry, 129(4), 1376-1382. https:// doi.org/10.1016/j.foodchem.2011.05.067 